\title{
ANTIBACTERIAL AND ANTIOXIDANT EFFECT OF SOME ESSENTIAL OILS AND NISIN IN MINCED BEEF DURING REFRIGERATED STORAGE
}

\author{
Walaa Mohamed Elkassas; Engy Fawzy Elbahy \\ Department of Food Hygiene, Animal Health Research Institute, \\ Kafr Elsheikh branch, Egypt
}

\begin{abstract}
The effect of the antioxidant and antibacterial activity of thyme, ginger, lemon grass oils and nisin (200ppm) on sensory, chemical ( $P H$, thiobarbituric acid "TBA" and total volatile nitrogen "TVN") and microbiological (aerobic plate count "APC", total coliform count and staphylococci count) quality of fresh minced beef during cold storage at $4^{\circ} C$ were studied. It is noticed that, all essential oils and nisin used had considerable effectiveness in decreasing aerobic plate count (APC), coliform count and staphylococci count, as well as chemical indices ( $p H, T B A$ and TVN). Sensory analysis indicated significant advantages in using lemon grass, ginger oils, nisin and thyme oil respectively, in refrigerated minced beef. Results indicated that the bacterial counts, $p H, T B A$ and TVN values decrease as the concentration of the oil increases since the concentration (1.5\%) gives the best effectiveness. The antioxidant and antibacterial activities of the added essential oils followed the order lemon grass oil > ginger oil > thyme oil. However, nisin was the lowest effect on the bacterial counts except staphylococci count. These results suggest that lemon grass, ginger and thyme oils respectively, can play an important role as antioxidant and antibacterial agents in refrigerated minced beef and extend the shelf life of refrigerated minced beef more than the control samples by 6 days, and however nisin need more research to be more stable and effective against Gram-negative bacteria.
\end{abstract}

Keyword: Antibacterial; Antioxidant; Essential oils; Nisin; Beef 


\section{INTRODUCTION}

Meat is a nutritious, protein-rich food which is highly perishable and has a short shelf-life unless preservation methods are used. Shelf life and maintenance of the meat quality are influenced by a number of interrelated factors including holding temperature, which can result in detrimental changes in the quality attributes of meat (Olaoye and Onilude, 2010). During storage, quality attributes of the product deteriorate due to lipid oxidation and microbial growth. Lipids oxidation is responsible for reduction in nutritional quality as well as changes in flavor (Aguirreźabal et al., 2000), while microbial contamination can precipitate major public health hazards and economic loss in terms of food poisoning and meat spoilage. Thus, the application of suitable agents possessing both antioxidant and antimicrobial activities may be useful for maintaining meat quality, extending shelf-life and preventing economic loss (Yin and Cheng, 2003). lipid oxidation and microbial growth in meat products can be controlled or minimized by using either synthetic or natural food additives (Mielnik et al., 2003).

Some spices and herbs used today are valued for their antimicrobial activities and medicinal effects in addition to their flavor and fragrance qualities. The extracts of many plant species have become popular in recent years and the attempts to characterize their bioactive principles have gained momentum for varied pharmaceutical and food processing applications (Shan et al., 2007). The antimicrobial activities of plant extracts form the basis for many applications, including raw and 
processed food preservation, pharmaceuticals, alternative medicines and natural therapies (Lis-Balchin and Deans, 1997).

Essential oils of herbs and their components, products from the secondary metabolism of plants, have many applications in ethnomedicine, food flavoring and preservation as well as the fragrance and pharmaceutical industries (Fabian et al., 2006).

Thyme is traditionally used as flavoring agents in meat and meat products. Recently, its essential oil is known to include carvacol, borneol, geraniol, but most importantly, thymol. Also Thyme oil contains a variety of flavonoids, these flavonoids increase thyme antioxidant capacity (Lawless, 1995 and Lacroix et al., 1997). The volatile oil components of thyme have also been known to have antimicrobial activity against different bacteria and fungi species (Dorman and Deans 2000; Nguefack et al., 2009).

The rhizome of the popular ginger species (Zinger officinal) is widely used as a spice and food seasoning due to its sweet aroma and pungent taste. It is well known to have antioxidant activity (Zia-urRehman et al., 2003) and effective antimicrobial agents (Ibrahim et al., 2011). Ginger has been also shown to have a powerful proteolytic activity and this property is especially useful in improving the tenderness quality of otherwise tough meat (Choi et al., 1999 and Naveena et al., 2004).

Lemon grass is a rich source of citral, which is used in perfumery and pharmaceutical industries, The biologically active constituent of 
lemon grass is citral constituting more than $75 \%(\mathrm{w} / \mathrm{w})$ of its essential oil (Huynh et al., 2008). Lemon grass essential oil has the ability to control bacterial growth and fungal pollutants in food such as Staphylococcus aureus and Escherichia coli, also the antioxidant activity of plant essential oil has proven, so that lemon grass essential oil in comparison with alpha-tocopherol has stronger antioxidant activity (Tizianna Baratta and Giuseppe, 1998).

Nisin is a bacteriocin generally recognized as safe (GRAS) by the US Food and Drug Administration and World Health Organization since 1969. It is produced by certain strains of Lactococcus lactis subsp. lactis, and is commercially available for use in foods (Guinane et al., 2005). It is active against gram-positive bacteria, but is not effective against gramnegative, yeast and mold. Nisin has been shown to be effective in controlling spoilage and pathogenic bacteria in many meat products (Cooksey, 2005 and Guerra et al., 2005), however nisin activity may be affected by many factors, such as concentration, the target microorganisms, interaction with food components, fat content and phosphate type, processing and storage conditions of food (Chollet et al., 2008).

In Relation to above, the objective of this study was to investigate the antioxidant as well as the antimicrobial effectiveness of three essential oils (thyme, ginger \& lemon grass oils) at various concentrations and nisin as bactericidal on the quality of fresh minced beef during refrigerated storage at $4^{\circ} \mathrm{C}$. 


\section{MATERIALS AND METHODS}

A grand total of $4 \mathrm{~kg}$ of fresh minced beef was purchased from butcher shop in Kafr Elsheikh city. The sample was transferred directly to the laboratory under complete aseptic conditions without undue delay. The samples were divided into five groups, untreated (control) and four treated groups. The treated groups were homogenized with thyme, ginger, lemon grass oils in $0.5 \%, 1 \%$ and $1.5 \%$ concentrations for each oil and nisin in the form of the commercial product Nisaplin, in an amount of 200 ppm (Hampikyan , 2009). Each sample was packed in polyethylene bag, labeled and stored at $4{ }^{\circ} \mathrm{C}$. Analyses were conducted initially (Zero day) and every 3 days intervals during storage as follows:

\section{Sensory examination:}

It was applied by using score system recommended by Pearson and Tauber (1984) according to the following table:

\begin{tabular}{|c||c||}
\hline Points & Interpretation of Quality \\
\hline 9 & Excellent \\
\hline 8 & Very very good \\
\hline 7 & Very good \\
\hline 6 & Good \\
\hline 5 & Medium \\
\hline 4 & Fair \\
\hline 3 & Poor \\
\hline 2 & Very poor \\
\hline 1 & Very very poor \\
\hline \hline
\end{tabular}




\section{Chemical examination includes:}

2.1. $\mathrm{PH}$ values were carried out according to (Pearson, 1984): The $\mathrm{pH}$ value was determined by using an electrical $\mathrm{pH}$ meter (Bye model 6020, USA).

2.2. Thiobarbituric acid (TBA): The method adopted for estimation of TBA by Vyncke (1970).

2.3. Total volatile nitrogen (TVN) was done according the technique recommended by Food and Agriculture Organization "FAO" (1980).

\section{Microbiological examination:}

3.1. Determination of aerobic plate count (APC): as recommended by the American Public Health Association for food stuff examination (APHA ,2001).

3.2. Determination of total coliforms count (MPN/g) which was done according to APHA (2001).

3.3. Determination of total staphylococci count which was performed according to APHA (2001). 


\section{RESULTS}

Table (1): Sensory evaluation of the untreated (control) and treated samples of minced beef during refrigerated storage at $4^{\circ} \mathrm{C}$

\begin{tabular}{|c|c|c|c|}
\hline Samples & Zero day & 3 day & 6 day \\
\hline Control & Very very good & Very poor & Very very poor \\
\hline Thyme oil & \multirow{2}{*}{ Very very good } & \multirow{2}{*}{ fair } & \multirow{2}{*}{ Very very poor } \\
\hline $0.5 \%$ & & & \\
\hline $1 \%$ & Very very good & medium & Very poor \\
\hline $1.5 \%$ & Very very good & medium & Very poor \\
\hline Ginger oil & \multirow{2}{*}{ Very very good } & \multirow{2}{*}{ medium } & \multirow{2}{*}{ Very poor } \\
\hline $0.5 \%$ & & & \\
\hline $1 \%$ & Very very good & good & fair \\
\hline $1.5 \%$ & Very very good & good & medium \\
\hline Lemon grass oil & \multirow{2}{*}{ Very very good } & \multirow{2}{*}{ medium } & \multirow{2}{*}{ poor } \\
\hline $0.5 \%$ & & & \\
\hline $1 \%$ & Very very good & Very good & good \\
\hline $1.5 \%$ & Very very good & Very good & good \\
\hline Nisin 200 ppm & Very very good & good & medium \\
\hline
\end{tabular}

Table (2): Mean values of chemical induces of the examined untreated (control) and treated samples of minced beef during refrigerated storage at $4^{\circ} \mathrm{C}$

\begin{tabular}{|c|c|c|c|c|c|c|c|c|c|}
\hline \multirow{2}{*}{ Samples } & \multicolumn{3}{|c|}{ PH } & \multicolumn{3}{|c|}{ TBA } & \multicolumn{3}{|c|}{ TVN } \\
\hline & Zero day & 3 day & 6 day & Zero day & 3 day & 6 day & Zero day & 3 day & 6 day \\
\hline Control & $5.64 \pm 0.02$ & $6.57 \pm 0.15$ & $7.13 \pm 0.24$ & $0.03 \pm 0.01$ & $0.97 \pm 0.12$ & $1.61 \pm 0.11$ & $4.28 \pm 0.03$ & $28.65 \pm 6.26$ & $46.94 \pm 9.33$ \\
\hline $\begin{array}{c}\text { Thyme oil } \\
0.5 \%\end{array}$ & $5.64 \pm 0.02$ & $6.29 \pm 0.19$ & $6.72 \pm 0.06$ & $0.03 \pm 0.01$ & $0.84 \pm 0.08$ & $1.37 \pm 0.12$ & $4.28 \pm 0.03$ & $20.43 \pm 3.19$ & $34.15 \pm 6.67$ \\
\hline $1 \%$ & $5.64 \pm 0.02$ & $6.11 \pm 0.27$ & $6.53 \pm 0.09$ & $0.03 \pm 0.01$ & $0.56 \pm 0.12$ & $1.08 \pm 0.13$ & $4.28 \pm 0.03$ & $18.12 \pm 7.75$ & $26.58 \pm 4.95$ \\
\hline $1.5 \%$ & $5.64 \pm 0.02$ & $6.07 \pm 0.16$ & $6.44 \pm 0.13$ & $0.03 \pm 0.01$ & $0.37 \pm 0.14$ & $0.96 \pm 0.07$ & $4.28 \pm 0.03$ & $14.96 \pm 1.12$ & $21.37 \pm 2.62$ \\
\hline $\begin{array}{c}\text { Ginger oil } \\
0.5 \%\end{array}$ & $\mid 5.64 \pm 0.02$ & $6.23 \pm 0.09$ & $6.59 \pm 0.14$ & $0.03 \pm 0.01$ & $0.58 \pm 0.05$ & $1.13 \pm 0.19$ & $4.28 \pm 0.03$ & $17.04 \pm 4.71$ & $29.61 \pm 3.91$ \\
\hline $1 \%$ & $5.64 \pm 0.02$ & $6.05 \pm 0.25$ & $6.38 \pm 0.12$ & $0.03 \pm 0.01$ & $0.34 \pm 0.15$ & $0.88 \pm 0.19$ & $4.28 \pm 0.03$ & $13.26 \pm 5.66$ & $19.46 \pm 4.39$ \\
\hline $1.5 \%$ & $5.64 \pm 0.02$ & $5.94 \pm 0.25$ & $6.30 \pm 0.12$ & $0.03 \pm 0.01$ & $0.29 \pm 0.08$ & $0.82 \pm 0.08$ & $4.28 \pm 0.03$ & $11.81 \pm 2.61$ & $18.02 \pm 2.39$ \\
\hline$\frac{\text { Lemon grass oil }}{0.5 \%}$ & $\mid 5.64 \pm 0.02$ & $6.15 \pm 0.26$ & $6.44 \pm 0.16$ & $0.03 \pm 0.01$ & $0.42 \pm 0.16$ & $0.95 \pm 0.18$ & $4.28 \pm 0.03$ & $15.48 \pm 4.41$ & $28.14 \pm 3.81$ \\
\hline $1 \%$ & $5.64 \pm 0.02$ & $5.97 \pm 0.23$ & $6.27 \pm 0.07$ & $0.03 \pm 0.01$ & $0.25 \pm 0.11$ & $0.76 \pm 0.18$ & $4.28 \pm 0.03$ & $9.06 \pm 1.27$ & $15.96 \pm 1.29$ \\
\hline $1.5 \%$ & $5.64 \pm 0.02$ & $5.91 \pm 0.35$ & $6.18 \pm 0.07$ & $0.03 \pm 0.01$ & $0.21 \pm 0.02$ & $0.74 \pm 0.13$ & $4.28 \pm 0.03$ & $8.32 \pm 4.14$ & $15.37 \pm 1.47$ \\
\hline Nisin 200 ppm & $5.64 \pm 0.02$ & $5.89 \pm 0.13$ & $6.15 \pm 0.12$ & $0.03 \pm 0.01$ & $0.19 \pm 0.06$ & $0.68 \pm 0.09$ & $4.28 \pm 0.03$ & $7.26 \pm 2.21$ & $13.60 \pm 3.14$ \\
\hline
\end{tabular}

Results represent as mean $\pm \mathrm{SE}$

TBA $0.9 \mathrm{mg}$ Melanoaldehyde / kg raw minced beef (EOS, 2005)

TVN $20 \mathrm{mg} / 100 \mathrm{gm}$ raw minced beef (EOS, 2005)

Kafrelsheikh Vet. Med. J. Vol. 11 No. 2 (2013) 
Antibacterial And Antioxidant Effect ...

Table (3): Mean values of APC of the examined untreated (control) and treated samples of minced beef during refrigerated storage at $4^{\circ} \mathrm{C}$

\begin{tabular}{|c|c|c|c|}
\hline \multirow{2}{*}{ Samples } & \multicolumn{3}{|c|}{ APC } \\
\hline & Zero day & 3 day & 6 day \\
\hline Control & $1.8 \times 10^{5} \pm 1.69 \times 10^{5}$ & $2.08 \times 10^{5} \pm 1.9 \times 10^{5}$ & $2.6 \times 10^{5} \pm 2.4 \times 10^{5}$ \\
\hline Thyme oil & \multirow{2}{*}{$1.8 \times 10^{5} \pm 1.69 \times 10^{5}$} & \multirow{2}{*}{$1.6 \times 10^{5} \pm 1.4 \times 10^{5}$} & \multirow{2}{*}{$2.4 \times 10^{5} \pm 2.2 \times 10^{5}$} \\
\hline $0.5 \%$ & & & \\
\hline $1 \%$ & $1.8 \times 10^{5} \pm 1.69 \times 10^{5}$ & $1.08 \times 10^{5} \pm 9.3 \times 10^{4}$ & $2.2 \times 10^{5} \pm 2.04 \times 10^{5}$ \\
\hline $1.5 \%$ & $1.8 \times 10^{5} \pm 1.69 \times 10^{5}$ & $1.3 \times 10^{5} \pm 1.2 \times 10^{5}$ & $5.5 \times 10^{3} \pm 5.5 \times 10^{3}$ \\
\hline Ginger oil & \multirow{2}{*}{$1.8 \times 10^{5} \pm 1.69 \times 10^{5}$} & \multirow{2}{*}{$1.3 \times 10^{5} \pm 1.13 \times 10^{5}$} & \multirow{2}{*}{$1.2 \times 10^{5} \pm 1.1 \times 10^{5}$} \\
\hline $0.5 \%$ & & & \\
\hline $1 \%$ & $1.8 \times 10^{5} \pm 1.69 \times 10^{5}$ & $1.07 \times 10^{5} \pm 9.4 \times 10^{4}$ & $2.1 \times 10^{5} \pm 1.99 \times 10^{5}$ \\
\hline $1.5 \%$ & $1.8 \times 10^{5} \pm 1.69 \times 10^{5}$ & $9.6 \times 10^{4} \pm 8.4 \times 10^{4}$ & $1.8 \times 10^{5} \pm 1.7 \times 10^{5}$ \\
\hline Lemon grass oil & \multirow{2}{*}{$1.8 \times 10^{5} \pm 1.69 \times 10^{5}$} & \multirow{2}{*}{$1 \times 10^{5} \pm 9 \times 10^{4}$} & \multirow{2}{*}{$2.1 \times 10^{5} \pm 1.9 \times 10^{5}$} \\
\hline $0.5 \%$ & & & \\
\hline $1 \%$ & $1.8 \times 10^{5} \pm 1.69 \times 10^{5}$ & $1.3 \times 10^{5} \pm 1.2 \times 10^{5}$ & $1.5 \times 10^{5} \pm 1.3 \times 10^{5}$ \\
\hline $1.5 \%$ & $1.8 \times 10^{5} \pm 1.69 \times 10^{5}$ & $7.9 \times 10^{4} \pm 7.1 \times 10^{4}$ & $1.06 \times 10^{5} \pm 9.4 \times 10^{4}$ \\
\hline Nisin 200 ppm & $1.8 \times 10^{5} \pm 1.69 \times 10^{5}$ & $1.6 \times 10^{5} \pm 1.45 \times 10^{5}$ & $1.02 \times 10^{5} \pm 1.1 \times 10^{5}$ \\
\hline
\end{tabular}

Results represent as mean $\pm \mathrm{SE}$

Table (4): Mean values of Coliform count of the examined untreated (control) and treated samples of minced beef during refrigerated storage at $4^{\circ} \mathrm{C}$

\begin{tabular}{|c|c|c|c|}
\hline \multirow{2}{*}{ Samples } & \multicolumn{3}{|c|}{ Coliform count } \\
\hline & Zero day & 3 day & 6 day \\
\hline Control & $1.9 \times 10^{4} \pm 4.8 \times 10^{3}$ & $4 \times 10^{3} \pm 8.5 \times 10^{2}$ & $5.5 \times 10^{3} \pm 1.5 \times 10^{3}$ \\
\hline Thyme oil & \multirow{2}{*}{$1.9 \times 10^{4} \pm 4.8 \times 10^{3}$} & \multirow{2}{*}{$3.2 \times 10^{3} \pm 8.5 \times 10^{2}$} & \multirow{2}{*}{$3.2 \times 10^{3} \pm 8.5 \times 10^{2}$} \\
\hline $0.5 \%$ & & & \\
\hline $1 \%$ & $1.9 \times 10^{4} \pm 4.8 \times 10^{3}$ & $2.1 \times 10^{4} \pm 5 \times 10^{2}$ & $2.1 \times 10^{3} \pm 5 \times 10$ \\
\hline $1.5 \%$ & $1.9 \times 10^{4} \pm 4.8 \times 10^{3}$ & $2.1 \times 10^{4} \pm 5 \times 10^{2}$ & $1.5 \times 10^{3} \pm 5 \times 10$ \\
\hline Ginger oil & \multirow{2}{*}{$1.9 \times 10^{4} \pm 4.8 \times 10^{3}$} & \multirow{2}{*}{$3.5 \times 10^{4} \pm 1.5 \times 10^{4}$} & \multirow{2}{*}{$8 \times 10^{3} \pm 1 \times 10^{3}$} \\
\hline $0.5 \%$ & & & \\
\hline $1 \%$ & $1.9 \times 10^{4} \pm 4.8 \times 10^{3}$ & $3.2 \times 10^{3} \pm 8.5 \times 10^{2}$ & $3.2 \times 10^{3} \pm 8.5 \times 10^{2}$ \\
\hline $1.5 \%$ & $1.9 \times 10^{4} \pm 4.8 \times 10^{3}$ & $8 \times 10^{3} \pm 1 \times 10^{3}$ & $2.1 \times 10^{4} \pm 5 \times 10^{2}$ \\
\hline Lemon grass oil & \multirow{2}{*}{$1.9 \times 10^{4} \pm 4.8 \times 10^{3}$} & \multirow{2}{*}{$2.2 \times 10^{3} \pm 1 \times 10^{2}$} & \multirow{2}{*}{$2.1 \times 10^{4} \pm 5 \times 10^{2}$} \\
\hline $0.5 \%$ & & & \\
\hline $1 \%$ & $1.9 \times 10^{4} \pm 4.8 \times 10^{3}$ & $1.2 \times 10^{4} \pm 3 \times 10^{3}$ & $3.2 \times 10^{3} \pm 8.5 \times 10^{2}$ \\
\hline $1.5 \%$ & $1.9 \times 10^{4} \pm 4.8 \times 10^{3}$ & $8 \times 10^{3} \pm 1 \times 10^{3}$ & $2.1 \times 10^{4} \pm 5 \times 10^{2}$ \\
\hline Nisin 200 ppm & $1.9 \times 10^{4} \pm 4.8 \times 10^{3}$ & $8 \times 10^{3} \pm 1 \times 10^{3}$ & $8 \times 10^{3} \pm 1 \times 10^{3}$ \\
\hline
\end{tabular}

Results represent as mean $\pm \mathrm{SE}$

Kafrelsheikh Vet. Med. J. Vol. 11 No. 2 (2013) 
Table (5): Mean values of Staphylococci count of the examined untreated (control) and treated samples of minced beef during refrigerated storage at $4^{\circ} \mathrm{C}$

\begin{tabular}{|c|c|c|c|}
\hline \multirow{2}{*}{ Samples } & \multicolumn{3}{|c|}{ Staphylococci count } \\
\hline & Zero day & 3 day & 6 day \\
\hline Control & $4 \times 10^{5} \pm 2.3 \times 10^{5}$ & $8.2 \times 10^{5} \pm 6.8 \times 10^{2}$ & $9.3 \times 10^{4} \pm 9.3 \times 10^{4}$ \\
\hline Thyme oil & \multirow{2}{*}{$4 \times 10^{5} \pm 2.3 \times 10^{5}$} & \multirow{2}{*}{$3.1 \times 10^{5} \pm 1.9 \times 10^{5}$} & \multirow{2}{*}{$2.3 \times 10^{5} \pm 7.4 \times 10^{4}$} \\
\hline $0.5 \%$ & & & \\
\hline $1 \%$ & $4 \times 10^{5} \pm 2.3 \times 10^{5}$ & $6.43 \times 10^{5} \pm 4.6 \times 10^{5}$ & $2.6 \times 10^{5} \pm 1.4 \times 10^{5}$ \\
\hline $1.5 \%$ & $4 \times 10^{5} \pm 2.3 \times 10^{5}$ & $1.6 \times 10^{6} \pm 1.4 \times 10^{6}$ & $4 \times 10^{4} \pm 4 \times 10^{4}$ \\
\hline Ginger oil & \multirow{2}{*}{$4 \times 10^{5} \pm 2.3 \times 10^{5}$} & \multirow{2}{*}{$1.7 \times 10^{5} \pm 3.3 \times 10^{4}$} & \multirow{2}{*}{$2.9 \times 10^{5} \pm 2.1 \times 10^{5}$} \\
\hline $0.5 \%$ & & & \\
\hline $1 \%$ & $4 \times 10^{5} \pm 2.3 \times 10^{5}$ & $3.3 \times 10^{5} \pm 1.7 \times 10^{5}$ & $1.7 \times 10^{5} \pm 1.3 \times 10^{5}$ \\
\hline $1.5 \%$ & $4 \times 10^{5} \pm 2.3 \times 10^{5}$ & $4.7 \times 10^{5} \pm 3.3 \times 10^{5}$ & $6 \times 10^{4} \pm 6 \times 10^{4}$ \\
\hline Lemon grass oil & \multirow{2}{*}{$4 \times 10^{5} \pm 2.3 \times 10^{5}$} & \multirow{2}{*}{$2.1 \times 10^{5} \pm 9.5 \times 10^{4}$} & \multirow{2}{*}{$1.5 \times 10^{5} \pm 4.8 \times 10^{4}$} \\
\hline $0.5 \%$ & & & \\
\hline $1 \%$ & $4 \times 10^{5} \pm 2.3 \times 10^{5}$ & $6.8 \times 10^{5} \pm 5.2 \times 10^{5}$ & $4.5 \times 10^{4} \pm 4.5 \times 10^{4}$ \\
\hline $1.5 \%$ & $4 \times 10^{5} \pm 2.3 \times 10^{5}$ & $9.8 \times 10^{4} \pm 2.5 \times 10^{3}$ & $9.8 \times 10^{4} \pm 2.5 \times 10^{3}$ \\
\hline Nisin 200 ppm & $4 \times 10^{5} \pm 2.3 \times 10^{5}$ & $1 \times 10^{4} \pm 1 \times 10^{4}$ & $2.5 \times 10^{4} \pm 2.5 \times 10^{4}$ \\
\hline
\end{tabular}

Results represent as mean $\pm \mathrm{SE}$

\section{DISCUSSION}

The results obtained in table (1) showed that the sensory properties of minced beef samples during refrigerated storage at $4^{\circ} \mathrm{C}$ were highly enhanced by addition of lemon grass oil followed by ginger oil , thyme oil at concentration $1.5 \%$ and $1 \%$ respectively an also nisin 200 ppm gave the same result compared to the control samples at zero, $3^{\text {rd }}$ and $6^{\text {th }}$ day of the storage period while the samples treated with $0.5 \%$ thyme oil demonstrated the lowest enhancement. Nearly similar results were obtained by Amany et al. (2010); Ibrahim et al. (2012) and Reham (2012). 
Lipid oxidation and other degradation reactions lead to the formation of low molecular compounds, which contribute to the sensory profile. Hydroperoxides and secondary oxidation products can react with protein and amino acids during processing and storage period affecting the flavor, odour and texture of meat products (Frankel, 1998).

Spoilage characteristics develop in food as microorganisms digest the sugars, complex carbohydrates, proteins and fats of food producing undesirable effects in the food if the spoilage microorganisms grow to significant levels. Typically, the threshold level for observation of food spoilage by odor, taste, or sight is not reached until the spoilage microflora exceeds about $10^{7}$ organisms/g of food (Sperber, 2009).

The results in table (2) showed an increase in PH mean values in different treatments during storage period by different rates. The untreated (control) samples showed the highest PH values. While the samples treated with nisin $200 \mathrm{ppm}$, lemon grass and ginger oils in concentrations $1.5 \%$ and $1 \%$ showed the highest effect on $\mathrm{PH}$ lowering its values than those of untreated respectively, followed by the samples treated with $1.5 \%$ and $1 \%$ thyme oil respectively, till the end of storage period. There was an increase in $\mathrm{PH}$ mean values of all untreated and treated samples at $6^{\text {th }}$ day of the storage period, this increase may be due to the accumulation of metabolites by bacterial action in meat and deaminations of proteins (Jay, 1996).

TBA value is widely used as indicator for the assessment of degree of lipid oxidation (EOS, 2005). The results obtained in table (2) revealed that the highest incremental rate of TBA value was recorded in the untreated samples, while the lowest significant incremental rate was 
recorded in samples treated with nisin 200 ppm followed by the samples treated with $1.5 \%, 1 \%$ lemon grass and ginger oils respectively, and finally the samples treated with $1.5 \%$ thyme oil. The increased rates of TBA values for all the stored samples with advancing the chilling storage time may be due to the auto-oxidation of meat lipids, bacteriological and/or oxidative rancidity. Limit of acceptance for TBA is proposed as $0.9 \mathrm{mg}$ Melanoaldehyde/ $\mathrm{kg}$ raw minced beef (EOS, 2005), and the rancid flavor is initially detected in meat products between TBA values of 0.5 and 2.0 (Gray and Pearson, 1987).

The use of metabolites produced by Lactobacillus (e.g. nisin) improved the sensory and biochemical quality criteria $(\mathrm{pH}$, TBA \& TVN) of frozen fish fillets (Ibrahim and Desouky, 2009). FernándezLópez et al. (2005) found that about $50 \%$ of the rancidity meat products can be controlled by the citrus preparations (e.g. lemon grass oil) with significant advantages in acceptability and aroma in rancidity-susceptible meat products. This antioxidant activity has been mainly attributed to flavonoids and ascorbic acid in citrus fruits (hesperidin, neohesperidin and eriocitrin) (Schwarz et al., 2001). And Zia-ur-Rehman et al. (2003) found that ginger has antioxidant activity. Thyme oil may act as a high scavenger of radicals involved in lipid peroxidation help in protecting lipids from oxidation during cold storage as discussed by Kulisic et al. (2005). Billing and Sherman, (1998) reported that Essential oils rich in polyphenols exhibit antioxidative activities as they scavenge free radicals, similar to synthetic phenolic antioxidants.

The mean values of TVN are given in table (2). With the progression of cold storage TVN rapidly increased for all investigated 
treatments occurred with different rates depending on the nature of treatments. The untreated samples showed the highest incremental rate while the treatments with nisin 200 ppm, 1.5\%, 1\% lemon grass and ginger oils respectively, followed by treatment with $1.5 \%$ thyme oil were more effective in delaying the rate of TVN increase during the subsequent cold storage.

TVN value was more useful for assessing the degree of meat deterioration than for evaluating the changes occurring during the first storage stages (El-Marrakchi et al.,1990). EOS (2005) stated that $20 \mathrm{mg}$ TVN/ 100 gm raw samples indicates the spoilage of minced meat. The increase in TVN is generally caused by the breakdown of proteins as a result of microbial activity under low temperature and autolytic and proteolytic enzymes. Such increases in TVN can be attributed to the volatile basis production and non-volatiles and those compensatory of free fatty acids resulting from lipids deterioration (Ibrahim and Desouky, 2009).

It is evident (Table, 3) that an increase in APC was noticed in control samples when compared with other treatments. This may indicate that essential oils and nisin caused sudden lethal effect for microorganisms. From the results in table (3) it could be observed that control samples had always high APC when compared with other treated samples during the subsequent cold storage, this may be attributed to the grinding process which compounds the problem by introducing the pathogens into the interior of the meat and contributes to the increase of total viable counts of meat (Mead and Griffin, 1998). It has been reported by Insausti et al. (2001) that meat spoilage can not be said to 
occur until TVC reach $10^{6}-10^{8} \mathrm{CFU} / \mathrm{g}$ (limit of microbiological acceptability). In general lemon grass oil and ginger oil in concentration $1.5 \%$ showed the highest effect in lowering APC at $3^{\text {rd }}$ day of cold storage while nisin showed the lowest effect.

Helal et al. (2006) revealed that antimicrobial activity of lemon grass oil has been reported higher against bacteria than fungi and yeast. Also, Jitoe et al. (1992) and Zia-ur-Rehman et al. (2003) found that ginger has effective antimicrobial activity.

Table (4) illustrates the effect of different treatments on total coliform counts in minced beef samples during storage at $4^{\circ} \mathrm{C}$. It is clear that lemon grass and ginger oils followed by thyme oil in different concentrations have the highest effect against the growth of coliforms compared to the control samples. it has been reported that extract of ginger showed an inhibitory activity against coliform bacteria (Kenar et al., 2010).

Data obtained in table (5) showed that the control samples had the highest staphylococci counts compared to other treatments. It is obvious that nisin 200ppm showed the lowest staphylococci counts followed by $1.5 \%$ lemon grass and ginger oils respectively. Similarly, Russell and Gould (2003) revealed that nisin delayed the growth of L.monocytogenes and Staphylococcus aureus but had no effect on Gram- negative bacteria. And lemon grass oil is reported to possess potent bactericidal activity against Gram positive and Gram negative bacteria (Sharma et al., 2003). Lemon grass oil was the most effective against Gram-positive bacteria followed by ginger and thyme (Lidiane et al., 2009). 


\section{CONCLUSION}

From the obtained results we can conclude that plant extracts and essential oils constitute a natural source of antimicrobial mixtures or pure compounds for centuries. Essential oils and purified components are used as natural products that prevent the growth of food-borne bacteria and molds in food systems, as well as extend the shelf-life of processed foods (Oke et al., 2009).

Biological properties of essential oils and their antimicrobial activity have been attributed to phenolic compound (Seydim and Sarikus, 2006). These compounds have hydrophobic characteristics and interact with different sites of microbial cell (e.g., cell wall and cytoplasmic membrane), causing loss of cellular constituents, collapse of membrane structure, and cell death (Burt, 2004).

The antimicrobial activity of thyme oil has been thoroughly investigated (Mielnik et al., 2008) and found to be active against food borne and spoilage flora (Solomakos et al., 2008). This significant rate of antibacterial activities is mostly attributable to the phenolic compounds (cavracrol) and to the hydrocarbons which can be bactericidal or bacteriostatic depending on their effective concentration (Bozin et al., 2006).

Ginger extract was reported to inhibit E. coli, Streptococcus faecalis, Salmonella typhimurium, Staphylococcus aureus, in meat and meat product. Several investigations in Japan reported that ginger or ginger extract added to lard or other foods showed reasonably strong antioxidant property (Nain et al., 2009). 
Moreover, lemon grass oil was observed to possess high antimicrobial activity, so it can be used as a way of combating the growth of common causes of food poisoning (Fisher and Phillips, 2006) and also this antimicrobial property make it an effective drug for bacterial and fungal infections (Bhoj et al., 2011). Lemon grass oil was found to be effective at all concentrations (Chahal et al., 2007), where it is composed of three main components, the alpha and beta-citral components which elicit antibacterial action on Gram-positive and Gram-negative organisms, while the third component is mycrene which provided enhanced activities when mixed with either of the two main previously identified components (Onawunmi et al., 1984).

The antimicrobial effect of nisin is caused by its interaction with the phospholipid components of the cytoplasmic membrane of the bacterial cell and thus, interference with membrane function (Henning et al., 1986). Use of nisin for meat preservation has not had much success. There are problems of low solubility, uneven distribution, and lack of stability on the meat surface, and nisin alone may not be sufficient to prevent spoilage, as gram-negative and nisin-resistant gram-positive bacteria such as lactic acid bacteria and are often associated with meat spoilage. Nisin with nitrite has been reported to be effective for the preservation of meat (Rayman et al., 1981).

So, addition of thyme, ginger and lemon grass oils showed general enhancement in sensory, chemical and microbial attributes due to the action of these oils in retarding oxidation as well as microbial population 
in the fresh minced meat during cold storage at $4^{\circ} \mathrm{C}$. The results of this study showed that lemon grass oil was the most effective especially at concentration $1.5 \%$ followed by ginger oil at the same concentration while thyme oil and nisin were the lowest. Therefore, it is suggested that lemon grass, ginger and thyme oils respectively, can be used as natural meat preservatives with both antioxidants and antimicrobial activities against food borne pathogens and spoilage organisms, and therefore may be useful in maintaining the meat quality, extending shelf- life of meat products, preventing economic loss and providing the consumer with food containing natural additives, which might be seen more healthful than those of synthetic origin. And continued research to bacteriocins (nisin) may lead to increased stability and enhanced features, or extension of the antimicrobial spectrum to Gram-negative bacteria and nisin-resistant gram-positive bacteria.

\section{REFERENCES}

- Aguirreźabal, M. M.; Mateo, J.; Domínguez, M. C. and Zumalacárregui, J. M. (2000): The effect of paprika, garlic and salt on rancidity in dry sausages. Meat Science, 54, 77-81.

- Amany, M. Salem; Reham, A. Amin and Gehan, S. A. Afifi (2010): Studies on antimicrobial and antioxidant efficiency of some essential oils in minced beef. Journal of American Science, 6(12).

- American Public Heath Association (APHA) (2001): Compendium of methods for the microbiological examination of foods. $4^{\text {th }} \mathrm{Ed}$., Washington, DC. 
- Bhoj Raj Singh; Vidya Singh; Raj Karan Singh and N. Ebibeni (2011): antimicrobial activity of lemongrass (Cymbopogon citratus) oil against microbes of environmental, clinical and food origin. Int. Res. J. Pharm. Pharmacol. Vol. 1(9) pp. 228-236.

- Billing, J. and Sherman, P. W. (1998): Antimicrobial functions of spices: Why some like it hot. The Quarterly Review of Biology, 73: 3- 49.

- Bozin, B.; Mimica- Dukie, N.; Simin, N. and Anackov, G. (2006): Characterization of the volatile composition of essential oils of some Lamiaceae spices and the antimicrobial and antioxidant activities of the entire oils. J. Agric. Food Chem. 54: 1822 - 1828.

- Burt, S. (2004): Essential oils: their antibacterial properties and potential applications in foods. Int J Food Microbiol. 94:233-253.

- Chahal, K. K.; Kumari, M.; Joia, B. S. and Chhabra, B. R. (2007): Chemistry and potential of lemon grass oil as stored grain protectant. Society of pesticide Science India, New Delhi, India. Pesticide Research J. 19 (2): 141- 144.

- Choi, K.H.; Laursen, R.A. and Allen, K.N. (1999): The 2.1Astructure of cysteine protease with proline specificity from ginger rhizome, Zingiberofficinale. Biochemistry-US 38, 11624-11633.

- Chollet, E.; Sebti, I.; Martial-Gros, A.; Degraeve, P. (2008): Nisin preliminary study as a potential preservative for sliced ripened cheese: $\mathrm{NaCl}$, fat and enzymes influence on nisin concentration and its antimicrobial activity. Food Control, 19, 982-989. 
- Cooksey, K. (2005): Effectiveness of antimicrobial food packaging materials. Food Additives and Contaminants, 22 (10), 980-987.

- Dorman, H.J.D. and Deans, S.G. (2000): Antimicrobial agents from plants: antibacterial activity of plant volatile oils. J. Appl. Microbiol., 88: 308.

- El-Marrakchi, A.; M. Bennour; N. Bouchriti; A. Hamama and H. Tagafait, (1990): Sensory, Chemical and Microbiological assessment of Moroccan sardines (Sardina pilchardus) stored in ice. J. Food Protec., 53: 0-5.

- Egyptian Organization for Standardization and Quality (EOS) (2005): Egyptian Standard, ES.

- Fabian, D.; Sabol M.; Domaracka, K. and Bujank Ova, D. (2006): Essential oils, their antimicrobial activity against $E$. coli and effect on intestinal cell viability. Toxicology in vitro J. 20: 1453- 1445.

- Fernàndez - López, J.; Zhi, N.; Aleson- Carbonell, L.; PerezAlvarez, J. A. and Kuri, V. (2005): Antioxidant and antibacterial activities of natural extracts: Application in beef meat balls. J. Meat Sci. 69: 371- 380 .

- Fisher, K. and Phillips, C. A. (2006): The effect of lemon, orange and bergamot essential oils and their components on the survival of Campylobacter jejuni, Escherichia coli $\mathrm{O}_{157}: H_{7}, \quad$ Listeria monocytogenes, Bacillus cereus and Staphylococcus aureus in vitro and in food systems. J. Appl. Microbiol. 101 (6): 1232- 1240. 
- Food and Agriculture Organization "FAO"(1980): Manual of Food Quality Control. FAO, United Nation, Rome, Italy.

- Frankel, E. N. (1998): Foods. In lipid oxidation volume 10 in the Oily Press Lipid Library, 187- 226. Glasgow, Scotland: Bell, Bain Ltd.

- Gray, J. I. and Pearson, A. M. (1987): Rancidity and warmed- over flavour. In: Pearson, A.M.; Duston, T.R., editors. Advances in meat research 3. NY. USA: Van Nostrand Company. 221- 269.

- Guerra, N.P.; Macías, C.L.; Agrasar, A.T.; Castro, L.P. (2005): Development of a bioactive packaging cellophane using nisaplin ${ }^{\circledR}$ as biopreservative agent. Lett. Appl. Microbiol., 40, 106-110.

- Guinane, C.M.; Cotter, P.D.; Hill, C.; Ross, R.P. (2005): A Review: Microbial solution to microbial problems; lactococcal bacteriocins for the control of undesirable biota in food. J. Appl. Microbiol., 98, 1316-1325.

- Hampikyan, H. (2009): Efficacy of nisin against Staphylococcus aureus in experimentally contaminated sucuk, a Turkish-type fermented sausage. J. Food Protec., 72: 1739-1743.

- Helal GA; Sarhan MM; Abu Shahla ANK and El-Khai EKA (2006): Antimicrobial activity of some essential oils against microorganisms deteriorating fruit juices. Mycobiol. 34: 219-229.

- Henning, S.; R. Metz, and W. P. Hammes. (1986): Studies on the mode of action of nisin. Int. J. Food Microbiol. 3:121-134. 
- Huynh KP.; Maridable J.; Gaspillo P.; Hasika M.; Malaluan R. and Kawasaki J. (2008): Essential oil from lemongrass extracted by supercritical carbon dioxide and steam distillation. The Phillippine Agric. Sci. 91:36-41.

- Ibrahim, A. Baker; Jalal, E. Alkass and Hatem, H. Saleh (2012): Antioxidant and antimicrobial effects of rosemary and ginger extract added to Karadi yearling lamb patties. Res. Opin. Anim. Vet. Sci., 2(2), 109-114.

- Ibrahim, H.M.; Abou-Arab, A.A. and Abu Salem, F.M. (2011): Antioxidant and antimicrobial effects of some natural plant extracts added to lamb patties during storage. Grasas Y Aceites, 62: 139-148.

- Ibrahim, S.M. and S.G. Desouky (2009): Effect of Antimicrobial Metabolites Produced by Lactic Acid Bacteria (Lab) on Quality Aspects of Frozen Tilapia (Oreochromis niloticus) Fillets. World J. Fish and Marine Sciences, 1: 40-45.

- Insausti,K.; M.J. Beriain; A. Purroy; P. Alberti; C. Gorraiz; C. Alzueta and M.J. Alzueta (2001): Shelf life of beef from local Spanish cattle breed stored under modified atmosphere. Meat Sci., 57: 273-781.

- Jay,J.M. (1996): Antioxidant. In: Modern Food Microbiology, Jay, J.M. (Ed). $4^{\text {th }}$ Edn., CBS Publishers and Distributers, New Delhi, India, pp: 265-266.

- Jitoe, A.; T. Masuda; I.P. Tengah; D.N. Suprapta; I.W. Gara and N. Nakatan (1992): Antioxidant activity of tropical ginger extract and analysis of the contained curcuminoids. J. Agric. Food Chem., 40: 1337-1340. 
- Kenar, M.; Ozogul, F. and Kuley, E. (2010): Effects of rosemary and sage tea extracts on the sensory, chemical and micrbiological changes of vacuumpacked and refriderated sardine (Sardina pilchardus) fillets. International Journal of Food Science and Technology, 45:23662372.

- Kulisic, T.; Radonic, A. and Milos, M. (2005): Antioxidant properties of thyme and wild thyme essential oils Italian J. Food Sci. 17: 315324.

- Lacroix, M.; Smoragicz, W.; Pazdernik, L.; Kone, M.I. and Krzystyniak, K. (1997): Prevention of lipid radiolysis by natural antioxidants from rose marry and thyme. Food Res. Int., 30: 457-462.

- Lawless, J. (1995): The illustrated encyclopedia of essential oils. Element books Ltd. Shaftesbury.UK.

- Lidiane Nunes Barbosa; Vera Lucia Mores Rall; Ana Ange' lica Henrique Fernandes; Priscila Ikeda Ushimaru; Isabella da Silva Probst and Ary Fernandes Jr. (2009): Essential oils against food borne pathogens and spoilage bacteria in minced meat. Food borne pathogens and disease, volume 6 , number 6.

- Lis-Balchin,M. and Deans, S.G. (1997): Bioactivity of selected plant essential oils against Listeria monocytogenes. Journal of Applied Microbiology 82, 759-762.

- Mead, P. S. and Griffin, P. G. (1998): Escherichia coli O157:H7. The Lancet vol. 352, October 10.

- Mielnik, M.B.; Aaby, K., and Skrede, G. (2003): Commercial antioxidants control lipid oxidation in mechanically deboned turkey meat. Meat Science, 65, 1147-1155. 
- Mielnik, M. B.; Signe, S.; Bjrg, E. and Grete, S. (2008): By-products from herbs essential oil production as ingredient in marinade for turkey thighs. LWT. 41: 93- 100.

- Nain, N.; Ahlawat, S. S.; Khanna, N. and Chhikara, S. K. (2009): Properties and utility of commonly used natural spices. Agric. Rev., 30 (2): 108 - 119.

- Naveena, B.M.; Mendiratta, S.K. and Anjaneyulu, A.S.R. (2004): Tenderization of buffalo meat using plant proteases from Cucumis trigonus roxb (Kachri) and Zingiber officinale roscoe (Ginger rhizome). Meat Sci. 68, 363-369.

- Nguefack, J.; Dongmo, J.B.; Dakole, C.D.; Leth, V.; Vismer, H.F.; Torp, J. and Nkengfack, A.E. (2009): Food preservative potential of essential oils and fractions from Cymbopogon citratus, Ocimum gratissimum and Thymus vulgaris against mycotoxigenic fungi. Int. J. Food Microbiol., 131: 151-156.

- Oke, F.; Aslim, B.; Ozturk, S. and Altundag, S. (2009): Essential oil composition, antimicrobial and antioxidant activities of Saturega cuneifolia Ten. Food Chemistry, 112:874-879.

- Olaoye, O.A. and Onilude, A.A. (2010): Investigation on the potential use of biological agents in the extension of fresh beef in Nigeria. World Journal of Microbiology and Biotechnology 26: 1445-1454, DOI: 10.1007/s11274-010-0319-5.

- Onawunmi, G. O.; Yisak, W. A. and Ogunlan, E. O. (1984): Antibacterial constituents in the essential oil of Cymbopogon citratus. Ethnopharmacol J. 12 (3): 279- 286. 
- Pearson, D. (1984): Chemical Analysis of Foods. $9^{\text {th }}$ Ed, publishing Co. Churchill livingstones, Edinburgh, London, United Kingdom.

- Pearson, M. and Tauber, W. (1984): Processed meat. $2^{\text {nd }}$ Ed, pp. 93 AVI Publishing Co., Inc. West Port, Connecticut, USA.

- Rayman, M. K.; Aris, B., and Hurst, A. (1981): Nisin: a possible alternative or adjunct to nitrate in the preservation of meat. Appl. Environ. Microbiol. 41:375-380.

- Reham, A. Amin (2012): Effect of bio preservation as a modern technology on quality aspects and microbial safety of minced beef. Global Journal of Biotechnology \& Biochemistry 7 (2): 38-49.

- Russell, N.J. and Gould, G.W. (2003): Food Preservatives. $2^{\text {nd }}$ Ed. Library of Congress cataloging in publication data. TP371. 2.F67,USA.

- Schwarz, K.; Bertelsen, G.; Nissen, L. R.; Gardner, P. T.; Heinonen, M. I. and Hopia, A. (2001): Investigation of plant extractsfor the protection of processed foods against lipid oxidation. Comparison of antioxidant assays based on radical scavenging, lipid oxidation and analysis of the principal antioxidant compounds. European Food Research Technology 212: 319-328.

- Seydim, AC. and Sarikus, G. (2006): Antimicrobial activity of whey protein based edible films incorporated with oregano, rosemary and garlic essential oils. Food Res Int. 39:639-644.

- Shan, B., Cai; Y-Z., Brooks; J.D. and Corke, H. (2007): The in vitro antibacterial activity of dietary spice and medicinal herb extracts. International Journal of Food Microbiology 117, 112 - 119. 
- Sharma, A.; Tayung, K.; Baruah, AKS. and Sharma, TC. (2003): Antibacterial activity of lemongrass [Cymbopogon fleuosus (Steud) Wats] inflorescence oil. Indian Perfum. 47:389-393.

- Solomakos, N.; Govaris, A.; Koidis, P. and Botsoglou, N. (2008): The antimicrobial effect of thyme essential oil, nisin, and their combination against Listeria monocytogenes in minced beef during refrigerated storage. J. Food Microbiol. 25 (1): 120- 127.

- Sperber, W.H. (2009): Introduction to the microbiological spoilage of foods and beverages. In: Sperber, W. H. and Doyle, M. P. (Eds). Compendium of the Microbiological Spoilage 1 of Foods and Beverages, Food Microbiology and Food Safety. DOI 10.1007/978-14419-0826-1_1, C_ Springer Science+Business Media, LLC.

- Tizianna Baratta, M. and R. Giuseppe, (1998): Antimicrobial and antioxidant properties of some commercial essential oils. Flavour and Fragrance, 13: 235-44.

- Vynche, W. (1970): Direct determination of thiobarbituric acid value in trichloroacetic acid extracts of fish as a measure of oxidative rancidity. Fetteseifen Astrichmitted, 2: 1084- 1094.

- Yin, M.C. and Cheng, W.S. (2003): Antioxidant and antimicrobial effects of four garlicderived organosulfur compounds in ground beef. Meat Science, 63, 23-28.

- Zia-ur-Rehman; Salariya, A.M. and Habib, F. (2003): Antioxidant activity of ginger extract in sunflower oil. Journal of the Science of Food and Agriculture, 83: 624-629. 


$$
\begin{aligned}
& \text { تأثير بعض الزيوت الطبيعية والنيسين كمضادات للبكتيريا و الأكسدة } \\
& \text { فى اللحم البقرى المفروم أثناء التخزين في الثناجة التحانة }
\end{aligned}
$$

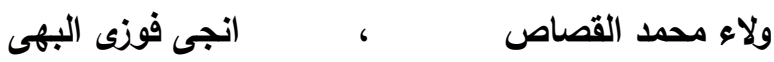

تم دراسة تأثير إضافة تركيزات مختلفة من زيوت الزعتر ، الزنجبيل وعشب الليمون بالإضافة إلى

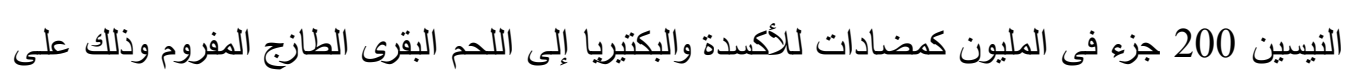

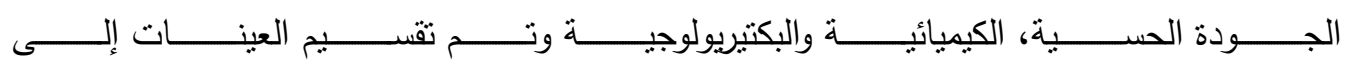
خمس مجموعات، المجموعة الضابطة والثلاثة مجموعات الأخرى تم خلطهم بالزيوت الثلاثة بتركيز 0.5\% ، 1\%، 1.5 \% على التوالى لكل نوع من الزيت أمسا المجموعة الخامسة فتم خلطها بالنيسين

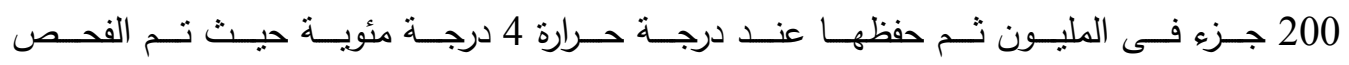
خلال فترات من 0، 3، 6 يوما. وأظهرت النتائج أن معالجة العينات بتركيزات مختلفة من زيت عشب درك الليمون والزنجبيل ثم زيت الزعتر على الترتيب والنيسين 200 جزء فى المليون أعطى نتيجة إيجابية فى الصفات الحسية والكيميائية والبكتيريولوجية وأن تركيز 5و 1\% من هذه الزيوت هو الأفضل تأثيرا. حيث أظهرت الدراسة أن هذه الزيوت لها تأثير خافض بشكل عام على العدد الكلى للبكتيريا الهوائية، العدد

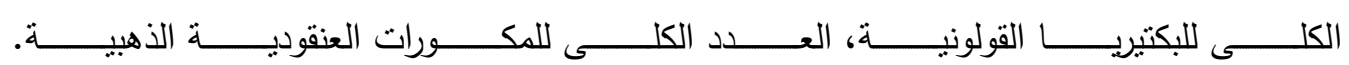
بالإضافة إلى إنخفاض فى قيمة الرقم الهيدروجينى، قيم حامض الثيوباريتيوريك، القواعد النينزوجينية

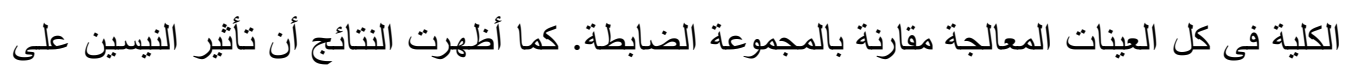

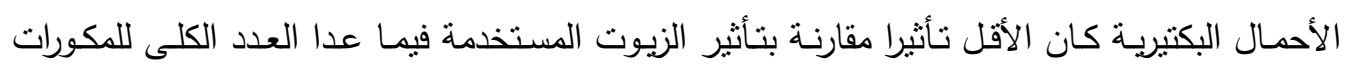
العنقودية الذهبية حيث كان تأثير النيسين هو الأقوى. هذا وقد أوصت الدراسة بإمكانية استخدام زيت

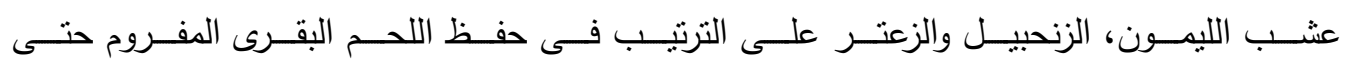
6 أيـام كبديل طبيعى للهواد الحافظـة الكيميائيـة ولتحسين الجودة وإطالـة فترة التخزين عند حفظها

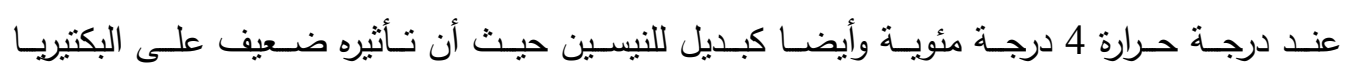

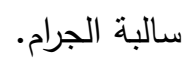

